\title{
Линейчатые фотоприемники формата $288 \times 4$ на основе ГЭС КРТ МЛЭ на подложках из кремния для диапазона 8-12.5 мкм
}

Г.Ю. Сидоров, И.В. Сабинина, Д.В. Марин, М.В. Якушев, Ю.Г. Сидоров, А.О. Сусляков, С.А. Дворецкий, В.В. Васильев, А.В. Зверев, Ю.С. Макаров, А.В. Предеин, А.В. Вишняков, Д.В. Горшков, В.Г. Ремесник

\author{
Институт физики полупроводников им. А.В. Ржанова СО РАН, \\ Новосибирск, 630090, пр. Ак. Лаврентьева, 13 \\ тел: (383)330-89-60, ракс: (383)333-27-71, эл.nочта: george@isp.nsc.ru
}

DOI 10.34077/RCSP2019-162

Проведен анализ возможности изготовления линейных фотоприемных модулей (ФПМ) длинноволнового инфракрасного (ДВИК) диапазона 8-12,5 мкм большого формата на основе соединения ГЭС КРТ МЛЭ, выращенного на подложках из кремния. Проведен анализ текущего состояния исследований в части крупноформатных ИК приемников, а также вопросов изготовления ДВИК ФПМ в мире и в России. Обоснована необходимость применения в составе фотоприемных устройств (ФПУ) на основе таких ФПМ микрокриогенных систем высокой производительности для охлаждения ниже температуры кипения азота.

Рассмотрены основные физические и технологические ограничения, возникающие при создании ДВИК фоточувствительных модулей большого формата. Показано, что неоднородность состава по площади выпускаемых в ИФП СО РАН ГЭС КРТ МЛЭ позволяет изготавливать ФПМ длиной не менее 32 мм. Обсуждается вопрос современной технологии изготовления кремниевых схем считывания (КСС) и показано, что возможно изготовление чипов размером до 16 см, однако с существенным снижением процента выхода годных. Оптимальный максимальный размер КСС составляет от 22 до 32 мм, в зависимости от технологии.

Обсуждаются вопросы влияния узкополосных фильтров на однородность сигнала и связанные с этим требования к материалу. Расчетным методом определена зависимость диффузионной длины, темнового и фототока фоточувствительных элементов (ФЧЭ) от электрофизических свойств материала и связанные с этим неоднородности сигнала. Обсуждается польза перехода от планарной технологии к меза-технологии и связанные с этим ограничения. Рассчитано влияние толщины рабочего слоя ГЭС КРТ на значение ДВ границы чувствительности фотодиодов. Проведен анализ величины неоднородности рабочего смещения на диодах. Рассчитано влияние температуры на ДВ границу ФЧЭ.

Проведен анализ вопросов гибридизации ФЧЭ и КСС больших размеров и форматов. Показано, что для текущего уровня технологии изготовления гибридных сборок методом flip-chip для ФЧЭ, на основе КРТ на подложках из кремния, возможно изготовления ФПМ размером до $40 \times 40$ мм либо линейчатого ФПМ длиной 58 мм. Обсуждается вопрос кривизны подложек из кремния.

Проведены экспериментальные исследования возможности изготовления ДВИК ФПМ на основе КРТ на подложках из кремния. Рассмотрены возможности и ограничения традиционной технологии. Обсуждаются возможности оптимизации конструкции ГЭС КРТ для еще большего повышения D*.

Величина обнаружительной способности в максимуме спектральной чувствительности $\mathrm{D}^{*}$, c учетом ВЗН, по 4 элементам для ИК ФПМ на основе ГЭС КРТ на подложке из кремния достигает значения $9.2 \times 10^{10} \Gamma_{ц}^{1 / 2} 2 \times$ см $\times$ Вт-1 для спектрального диапазона от 8 до 12,5 мкм при температуре $65 К$ с использованием отсекающего коротковолнового фильтра.

Разработаны предложения по созданию ФПМ ИК диапазона на основе ГЭС КРТ на подложках из кремния увеличенной размерности для ДВИК диапазона. Сформулированы дальнейшие направления исследований для повышения характеристик таких ФПМ, а также создания ФПУ на их основе. 